\title{
BIOCONTROL OF TEAK CANKER CAUSED BY Lasiodiplodia theobromae ${ }^{1}$
}

\author{
Rafaela Cristina Ferreira Borges ${ }^{2}$, Eder Marques ${ }^{3 *}$, Monica Alves Macedo ${ }^{3}$, Irene Martins ${ }^{4}$, José Getulio \\ da Silva Filho ${ }^{5}$ and Sueli Correa Marques de Mello $^{6 *}$
}

\footnotetext{
${ }^{1}$ Received on 29.01.2018 accepted for publication on 23.07.2018.

${ }^{2}$ Universidade de Brasília, Doutoranda em Fitopatologia, Departamento de Fitopatologia, Brasília, DF-Brasil. E-mail: $<$ rafaelafal@hotmail.com>.

${ }^{3}$ Universidade de Brasília, Doutor em Fitopatologia, Brasília, DF-Brasil. E-mail: <eder.marques.08@gmail.com>and $<$ monica.macedo.unb@gmail.com>.

${ }^{4}$ Empresa Brasileira de Pesquisa Agropecuária, Centro Nacional de Pesquisa de Recursos Genéticos e Biotecnologia, Laboratório de Fitopatologia, Analista A, Mestre em Agronomia, Brasília, DF-Brasil. E-mail: <irene.martins@embrapa.br>.

${ }^{5}$ Empresa Brasileira de Pesquisa Agropecuária, Analista A, Laboratório de Biologia Celular, Mestre em Botânica, Ponte AltaGama, Brasília, DF-Brasil. E-mail: <jose-getulio.silva@embrapa.br>.

${ }^{6}$ Empresa Brasileira de Pesquisa Agropecuária, Centro Nacional de Pesquisa de Recursos Genéticos e Biotecnologia, Laboratório de Fitopatologia, Pesquisadora A, Brasília, DF-Brasil. E-mail: <sueli.mello@embrapa.br>.

*Corresponding author.
}

\begin{abstract}
Teak is a forest species that has assumed great importance in Brazil, where it has found excellent conditions for development since its introduction into the country in the 1960s. However, phytosanitary problems are beginning to threaten the production of this timber species. An example is teak canker, caused by the fungus Lasiodiplodia theobromae ( $\mathrm{Lt}$ ), which has only recently been reported in Brazil, and for which, therefore, there are no recommended control methods. Thus, this study evaluated the control of this pathogen, investigating the potential of the biocontrol agents (BCAs) Trichoderma spp., Bacillus sp. and Enterobacter sp., initially through in vitro assays and, subsequently, with in vivo tests. According to the in vitro assay results, the Trichoderma isolates CEN162 and CEN1153 and the strain of Bacillus sp. (UnB1366) were the treatments that stood out, as they were able to completely inhibit mycelial growth of some isolates of Lt. When these isolates were tested in a preventive way, the control levels varied depending on the Lt isolate and the antagonistclone interaction, where CEN162 (T. asperellum) and UnB166 (Bacillus sp.) showed 100\% control. Thus, there is a positive correlation between the in vitro and in vivo tests, since the same BCAs stood out. Although good levels of control have been obtained with the BCAs used, it can be concluded that there is a variation in the antagonism to different $\mathrm{Lt}$ isolates or even in the antagonist-clone interaction, corroborating the information available in the scientific literature on this plant-pathogenic fungus.
\end{abstract}

Keywords: Biocontrol agents; Forestry; Teak disease management.

\section{CONTROLE BIOLÓGICO DO CANCRO DA TECA CAUSADO POR Lasiodiplodia theobromae}

RESUMO - A teca é uma espécie florestal que assumiu grande importância no Brasil, onde encontrou excelentes condições de desenvolvimento desde a sua introdução na década de 1960. Entretanto, problemas fitossanitários começam a ameaçar a exploração desta espécie madeireira. Um exemplo é o cancro da teca, causado pelo fungo Lasiodiplodia theobromae (Lt), cuja etiologia foi recentemente elucidada no Brasil e, portanto, ainda não existem métodos de controle recomendados. Sendo assim, o objetivo deste trabalho foi avaliar o controle deste patógeno, investigando o potencial dos agentes de controle biológico (ACB) Trichoderma spp., Bacillus sp. e Enterobacter sp., inicialmente por meio de ensaios in vitro e, posteriormente, com realização de testes in vivo. De acordo com os resultados dos testes in vitro, os isolados de Trichoderma CEN162 e CEN1153 e a estirpe UnB1366 de Bacillus sp., foram os tratamentos que se destacaram, sendo capazes de inibir completamente 
o crescimento micelial de alguns isolados de Lt. Quando esses isolados foram testados de forma preventiva, observou-se variação nos níveis de controle, dependendo do isolado de Lt e da interação antagonista-clone, onde CEN162 (T. asperellum) e UnB166 (Bacillus sp.) apresentaram 100\% de controle. Dessa forma, houve uma correlação positiva entre os testes in vitro e in vivo, uma vez que os mesmos ACB se destacaram. Apesar de ter-se obtido bons níveis de controle com os ACB utilizados, pode-se concluir que existe uma variação no antagonismo a diferentes isolados ou mesmo na interação antagonista-clone, corroborando as informações disponíveis na literatura científica sobre este fungo fitopatogênico.

Palavras-Chave: Agentes de controle biológico; Manejo de doenças da teca; Silvicultura.

\section{INTRODUCTION}

Teak (Tectona grandis Linn, F.) was introduced in Brazil in the 1960s, initially in the State of Mato Grosso, and its cultivation expanded to other Brazilian states. This forest species has high commercial value, which has led Brazil to invest in breeding programs, focusing on rapid growth and productivity. Its timber can be used for the manufacture of fine furniture, frames, floors, shipbuilding and panels (Goh and Galiana, 2000).

The major diseases that affect teak plantations are fungal ones, such as rust, caused by Olivea tectonae T.S. Ramakr and K. Ramakr (Arguedas, 2004); Ceratocystis wilt, caused by Ceratocystis fimbriata Ell. and Halst (Firmino et al., 2012), and canker, often associated with Lasiodiplodia theobromae (Lt) Patouillard Griffon and Maublanc (Borges et al., 2015). Lt infects a large number of plants in different botanical families. Therefore, it is a cosmopolitan fungus, polyphagous and opportunistic, with reduced pathogenic specialization, whose occurrence has been reported in several regions, causing the most varied symptoms (Punithalingam, 1980). Due to the high genetic diversity of this pathogen, it is difficult to control the disease. According to Pereira et al. (2012), isolates of Lt from papaya showed low sensitivity to the fungicides of the thiabendazole group in Brazil. Thus, preventive or curative chemical control, employed in isolation, is not efficient, requiring the adoption of other management measures (Sales Júnior et al., 2009).

Since there are few registered phytosanitary products for forestry, regardless of the target pathogen, the use of alternative control methods, such as biological control agents (BCAs), deserves attention not only because they meet the demand for alternative controls that are safe and effective, but also because they meet the protocol requirements of certifications related to the international market (Benato, 2003). It is known that species of Trichoderma, Bacillus and some natural

Revista Árvore. 2018;42(3):e420304 compounds derived from plants have fungistatic or fungicidal effects (Bautista-Baños et al., 2006) and can be used in the management of plant diseases. However, there are few studies related to the teak-canker pathosystem.

Levels of biological control against a target organism are intra and interspecifically variable, and this variation also occurs between isolates of antagonistic microorganisms (Dennis and Webster, 1971; Brodeur, 2012; Marques et al., 2018). In forest plants, some studies have reported satisfactory levels of biocontrol of plant pathogens both in vitro (Marques and Uesugi, 2017; Adeniyi et al., 2013, Briceño et al., 2008, Kupper et al., 2004, Mortuza and Ilag, 1999) and in vivo (Maciel et al., 2017, Sultana and Ghaffar, 2010).

The increasing spread of diseases caused by $L$. theobromae is responsible for extensive losses in productive systems. In Brazil, teak canker represents a threat to plantations in states that have commercial plantations. Studies that aim to improve the control of this disease, by means of efficient measures, represent an important demand. Therefore, this study evaluated in vitro and in vivo control of teak canker using three different agents of biological control.

\section{MATERIALAND METHODS}

\subsection{Origin of teak plant material, pathogen isolates and BCAs}

Two clones of teak, identified here as clone $\mathrm{A}$ and clone B, were used at 180 days of age, obtained from production nurseries, located in the West of Mato Grosso State.

Five isolates of Lt obtained from teak plantations and previously characterized by Borges et al. (2015) were used (Table 1). Nine Trichoderma isolates used in the experiments, obtained from soils under different crops, 
belong to the Collection of Fungi for the Control of Plant Pathogens and Weeds of Embrapa Cenargen (Brazilian Agricultural Research Corporation) previously characterized by molecular identification (Borges, 2014). The isolates of Bacillus and Enterobacter (Table 1) were recovered from the Collection of Plant Pathogenic Bacteria of the University of Brasília, previously characterized by Marques and Uesugi (2017) and Marques et al. (2013, 2014).

\subsection{Evaluation of the in vitro antagonism of Trichoderma spp.}

The antagonistic potential of the Trichoderma isolates against $\mathrm{Lt}$ was evaluated by the dual culture technique (Dennis and Webster, 1971). Agar discs (5 $\mathrm{mm}$ ) containing the fungal structures, removed from the pathogen and antagonist monosporic cultures, were placed on opposite sides of 90-mm Petri dishes containing commercial PDA (Potato-Dextrose-Agar) medium. The cultures were incubated at $25^{\circ} \mathrm{C}$, with $12 \mathrm{~h}$ of light. Control plates were prepared with pathogen and without the antagonist. The evaluations were done after seven days of incubation, when the pathogen in the control plates reached the maximum growth, according to the scale of classes proposed by Bell et al. (1982):
- Class 1 - Trichoderma completely overgrew the pathogen and covered the entire medium surface;

- Class 2 - Trichoderma overgrew at least twothirds of the medium surface;

- Class 3 - Trichoderma and the pathogen each colonized approximately one-half of the medium surface (more than one-third and less than two-thirds) and neither organism appeared to dominate the other;

- Class 4 - The pathogen colonized at least twothirds of the medium surface and appeared to withstand encroachment by Trichoderma;

- Class 5 - The pathogen completely overgrew the Trichoderma and occupied the entire medium surface.

The experimental design was completely randomized, in a 9x5 double factorial (nine isolates of Trichoderma $\mathrm{x}$ five isolates of $\mathrm{Lt}$ ) and four replicates, where each plot was represented by a $90 \mathrm{~mm}$ Petri dish. The experiment was performed twice.

The analysis of variance (ANOVA) was done, and the averages grouped by the Scott-Knott test at 5\% probability, using the statistical program SISVAR v.5.0 (Ferreira, 2007).

Table 1 - Description of the microorganisms used in this study. Tabela 1 - Descrição dos microrganismos utilizados neste estudo.

\begin{tabular}{|c|c|c|c|}
\hline Collection code & Origin & Location & Identification \\
\hline CEN162 & Soil cultivated with rice & Distrito Federal & T. asperellum \\
\hline CEN201 & Rhizosphere of Vochyziaceae & Mato Grosso & T. asperellum \\
\hline CEN209 & Soil cultivated with copaiba & Distrito Federal & T. koningiopsis \\
\hline CEN234 & Soil cultivated with cotton & Solo & T. harzianum \\
\hline CEN515 & Soil cultivated with eucalypts & Goiás & T. asperellum \\
\hline CEN522 & Guava orchard soil & Pernambuco & T. brevicompactum \\
\hline CEN1149 & Soil cultivated with teak & Mato Grosso & T. harzianum \\
\hline CEN1151 & Soil cultivated with teak & Mato Grosso & T. harzianum \\
\hline CEN1153 & Soil cultivated with teak & Mato Grosso & T. harzianum \\
\hline UnB1366 & Cerrado soil & Distrito Federal & Bacillus sp. \\
\hline UnB1367 & Cerrado soil & Distrito Federal & Enterobacter sp. \\
\hline UnB1368 & Cerrado soil & Distrito Federal & Bacillus sp. \\
\hline UnB1369 & Cerrado soil & Distrito Federal & Enterobacter sp. \\
\hline UnB1370 & Cerrado soil & Distrito Federal & Enterobacter sp. \\
\hline UnB1371 & Cerrado soil & Distrito Federal & Enterobacter sp. \\
\hline UnB1372 & Cerrado soil & Distrito Federal & Bacillus sp. \\
\hline UnB1374 & Cerrado soil & Distrito Federal & Enterobacter sp. \\
\hline UnB1375 & Cerrado soil & Distrito Federal & Bacillus sp. \\
\hline CEN1224 & Teak & Mato Grosso & L. theobromae \\
\hline CEN1225 & Teak & Mato Grosso & L. theobromae \\
\hline CEN1226 & Teak & Mato Grosso & L. theobromae \\
\hline CEN1227 & Teak & Mato Grosso & L. theobromae \\
\hline CEN1228 & Teak & Mato Grosso & L. theobromae \\
\hline
\end{tabular}




\subsection{Evaluation of the in vitro antagonism of Bacillus sp. and Enterobacter sp.}

For the evaluation of the antagonistic potential of bacterial strains (five Enterobacter sp. and four Bacillus sp.), the dual culture technique (Dennis and Webster, 1971) was performed in a similar manner to that previously described for evaluations of Trichoderma isolates. A portion of the bacterial mass, previously cultured in PDA, was placed at the periphery of the PDA plates, using a sterile needle. After two days, a 6-mm diameter disc of the pathogen ( $\mathrm{Lt}$ ) was placed on the opposite end of the plate containing the BCA and incubated at $25 \pm 1{ }^{\circ} \mathrm{C}$ with $12 \mathrm{~h}$ of light.

The experimental design was completely randomized, similarly to that previously described for the tests with Trichoderma.

The average diameter values of the inhibition halos were generated from the reading, every 24 hours, using the measurements of colony diameter in two perpendicular directions with a ruler. The measurements were concluded when the entire surface of the medium was colonized by the pathogen on the control plate (containing only the pathogen). The data obtained were used to calculate the inhibition Index of Mycelial Growth of the pathogen, according to Menten et al. (1976), using the equation: $\operatorname{IMG}(\%)=\left[\left(D_{\text {ctreat }}-D_{\text {treat }}\right) / D_{\text {ctreat }}\right] \times 100$, where $D_{\text {ctreat }}=$ diameter of the radial mycelial growth of the pathogen in the control treatment without bacteria; $\mathrm{D}_{\text {treat }}=$ diameter of the radial mycelial growth of the pathogen in the treatment with bacteria. Statistical analysis was done as described above.

\subsection{In vivo assays of Lasiodiplodia theobromae on teak cuttings}

In these experiments, two Trichoderma isolates (CEN162 and CEN1153) were used. Inoculants of the antagonists were produced in transparent polypropylene plastic bags containing moistened and autoclaved rice grains. Incubation of the cultures occurred at $25 \pm 2{ }^{\circ} \mathrm{C}$ with a 12-h photoperiod (Papavizas, 1982; Silva, 1997). The inoculation was done by the addition of $20 \mathrm{~g}$ of rice colonized with Trichoderma (on average $3.7 \times 10^{9}$ conidia, per gram of rice), for each $100 \mathrm{~g}$ of autoclaved red latosol, under greenhouse conditions. Each pot $(5 \mathrm{~L})$ received $75 \mathrm{~g}$ of fertilizer (4-14-8) at the time of transplant. The control treatment used the same amount of autoclaved rice grains.
The bacterial isolate UnB1366 (Bacillus sp.) was used in the concentration of $10^{9} \mathrm{CFU} \mathrm{mL}^{-1}$ (colonyforming units) prepared in a comparative manner with the McFarland scale (Scale 7 equivalent). The bacterial suspension was sprayed manually on shoots of the plants. A plastic cover was used on the neighboring plots to avoid drift. The control treatment used was sterilized distilled water without bacteria.

Twenty-four hours after the inoculation of the biocontrol agents, the pathogen was inoculated in 4-month-old cuttings. Lt isolates CEN1224 and CEN1226 were inoculated into both clones, using the methodology described by Pereira et al. (2006), with adaptations: The inoculum was deposited in the stem, between the bark and the wood through a 2$\mathrm{cm}$ long incision, made with the aid of a stylet, $5 \mathrm{~cm}$ above the soil line. A disc ( $2 \mathrm{~mm}$ diameter) of PDA containing mycelium of the fungus was deposited in each incision (one per plant). The wound was covered with a moistened cotton ball and sealed with PVC film, to avoid drying and the entry of other microorganisms. Control plants received a PDA disc without the pathogen.

After 60 days, the efficacy of the BCAs was evaluated, using the disease scale adapted from Pereira et al. (2006). This scale varies from 0 to 4 , determined on the basis of disease severity:

- 0 - cuttings with no visible lesion = highly resistant;

- 1 - lesion up to $3 \mathrm{~cm}$ long = resistant;

- 2- lesion up to $6 \mathrm{~cm}$ long = medium resistant;

- 3- lesion length greater than $6 \mathrm{~cm}=$ susceptible and;

- 4- cuttings with deep lesion, darkening of veins, leaf fall and dead cuttings = highly susceptible.

The experiment was conducted in a completely randomized design in a $3 \times 2 \times 2$ triple factorial scheme (antagonist $x$ clones $x$ pathogen isolates), with five replications, where each plant was an experimental unit.

The analysis of variance (ANOVA) was done, followed by the Scott-Knott average comparison test at $5 \%$ probability level, using the statistical program SISVAR v.5.0 (Ferreira, 2007).

\section{RESULTS}

\subsection{In vitro antagonism of BCAs}

All isolates of Trichoderma differed statistically from the control (Table 2). Isolates CEN162 and CEN1153 exerted

Revista Árvore. 2018;42(3):e420304 
a total antagonistic effect on the mycelial growth of the pathogen, not statistically differing from each other. Isolates CEN201 (2.6), CEN1149 (2.9), CEN234 (2.9), CEN515 (3.0) and CEN209 (2.8) received the highest IMG values in the evaluations; therefore, they did not promote total inhibition of pathogen growth and also did not differ statistically among themselves. It was also observed that the isolates of Lt CEN1225 (2.6) and CEN1226 (2.7) showed the highest averages relative to mycelial growth, differing significantly from each other. Isolates CEN1224 (2.6), CEN1227 (2.8) and CEN1228 (2.9), on the other hand, showed lower scores, not statistically different from each other. No significant differences were observed in relation to the growth of $\mathrm{Lt}$ CEN1225, CEN1226, CEN1227 and CEN1228 isolates used in the in vitro assay. In contrast, isolate Lt CEN1224 had a lower average, differing statistically from the others. The interaction between Trichoderma isolates and L. theobromae isolates was not significant at $5 \%$ probability.

Among the bacteria (Table 2), isolate UnB1366 (Bacillus sp.) significantly inhibited the mycelial growth of $\mathrm{Lt}$ (45.5), differing from the others. The isolate with the second greatest inhibition was UnB1375 (28.6), followed by UnB1368 (17.8), UnB1367 (14.1) and UnB1370 (10.8). The others did not differ significantly from the control treatment; therefore, they did not present an antagonistic effect on the mycelial growth of Lt. It was also observed that isolate LtCEN1226(22.0) presented the greatest average of mycelial growth, followed by Lt CEN1225 (16.9). Isolates CEN1224 (10.8), CEN1227 (10.4) and CEN1228 (9.9), in contrast, presented lower values, not statistically different among themselves.

Considering the interaction between antagonistic bacterial isolates and Lt isolates, it was observed that isolate UnB1375 (Bacillus sp.) showed partial suppression of the development of most of the isolates, except for isolate CEN1225, which did not show sensitivity when subjected to this treatment. Bacterial isolate 1367 (Enterobacter $\mathrm{sp}$.) inhibited the mycelial growth of CEN1225 (17.6), CEN1226 (16.7) and CEN1227 (19.8), not differing statistically from each other, but differing from isolates CEN1224 (9.6) and CEN1228 (7.0), which presented less sensitivity in the presence of this antagonist. It was observed that when the pathogen isolates CEN1224(14.6), CEN1225 (14.1) and CEN1226 (12.0) were subjected to bacterial isolate UnB1369 (Enterobacter sp.) a reduction of approximately $15 \%$ occurred in mycelial growth, differing statistically only from isolates CEN1227 and CEN1228, for which there was no growth inhibition. Bacterial isolate UnB1371 (Enterobacter $\mathrm{sp}$.) showed no antagonistic effect on most of the isolates of Lt tested, except for isolate CEN1225, which presented $16.7 \%$ inhibition. All the other bacterial isolates evaluated in this study exerted partial control on mycelial growth of most of the Lt isolates (Table 3).

Table 2 - Averages obtained in the in vitro assay of Trichoderma and bacterial isolates, relative to the inhibition of mycelial growth of Lasiodiplodia theobromae isolates.

Tabela 2 -Valores médios das notas obtidas no ensaio in vitro de isolados de Trichoderma e de bactérias, relativos à inibição do crescimento micelial de isolados Lasiodiplodia theobromae.

\begin{tabular}{|c|c|c|c|c|c|c|c|c|c|}
\hline & \multicolumn{9}{|c|}{ Antagonistic fungi } \\
\hline $\begin{array}{l}\text { Control } \\
\text { treatment }\end{array}$ & CEN201 & CEN1149 & CEN234 & CEN515 & CEN209 & CEN162 & CEN1153 & CEN522 & EN1151 \\
\hline \multirow[t]{5}{*}{$5.00 \mathrm{a}$} & $2.6 \mathrm{c}^{*}$ & $2.9 \mathrm{c}$ & $2.9 \mathrm{c}$ & $3.0 \mathrm{bc}$ & $2.8 \mathrm{c}$ & $1.0 \mathrm{~d}$ & $1.0 \mathrm{~d}$ & $3.4 \mathrm{~b}$ & $2.8 \mathrm{c}$ \\
\hline & \multicolumn{9}{|c|}{ Lasiodiplodia isolates } \\
\hline & CEN1224 & & CEN1225 & & CEN1226 & & CEN1227 & & CEN1228 \\
\hline & $2.6 \mathrm{~b}$ & & $2.8 \mathrm{ab}^{*}$ & & $2.7 \mathrm{ab}$ & & $2.8 \mathrm{ab}$ & & $2.9 \mathrm{a}$ \\
\hline & \multicolumn{9}{|c|}{ Antagonistic bacteria } \\
\hline $\begin{array}{l}\text { Control } \\
\text { treatment }\end{array}$ & UnB1366 & UnB1367 & UnB1368 & UnB1369 & UnB 1370 & UnB1371 & UnB1372 & UnB1374 & UnB1375 \\
\hline \multirow[t]{4}{*}{$0.00 \mathrm{a}$} & $45.5 \mathrm{f}$ & $14.1 \mathrm{c}$ & $17.8 \mathrm{~d}$ & $8.1 \mathrm{~b}$ & $10.8 \mathrm{c}$ & $3.3 \mathrm{a}$ & $2.9 \mathrm{a}$ & $4.2 \mathrm{a}$ & $28.6 \mathrm{e}$ \\
\hline & \multicolumn{9}{|c|}{ Lasiodiplodia isolates } \\
\hline & CEN1224 & & CEN1225 & & CEN1226 & & CEN1227 & & CEN1228 \\
\hline & $10.8 \mathrm{a}$ & & $16.9 \mathrm{~b}$ & & $22.0 \mathrm{c}$ & & $10.4 \mathrm{a}$ & & $9.7 \mathrm{a}$ \\
\hline
\end{tabular}

Averages followed by the same lowercase letter in the column, and uppercase in the row, do not differ significantly by the Scott-Knott test $(\mathrm{P}<0.05)$

Médias seguidas pela mesma letra minúscula na coluna, e maiúscula na linha, não diferem significativamente pelo teste Scott-Knott $(\mathrm{P}<0,05)$. 
Table 3 - Results of the significant interaction of the percentage of in vitro mycelial growth inhibition of five Lasiodiplodia theobromae isolates through the antagonistic effect of nine bacterial strains (Bacillus and Enterobacter).

Tabela 3 - Resultado da interação significativa da porcentagem de inibição do crescimento micelial in vitro, de cinco isolados de Lasiodiplodia theobromae, pelo efeito antagônico de nove isolados bacterianos (Bacillus e Enterobacter).

\begin{tabular}{|c|c|c|c|c|c|}
\hline \multirow{2}{*}{$\begin{array}{c}\text { Bacterial antagonist } \\
\text { isolates }\end{array}$} & \multicolumn{5}{|c|}{ Lasiodiplodia isolates } \\
\hline & CEN1224 & CEN1225 & CEN1226 & CEN1227 & CEN1228 \\
\hline UnB1366 & $13.9 \mathrm{bA}^{*}$ & $100.0 \mathrm{cB}$ & $100.0 \mathrm{Db}$ & $7.6 \mathrm{bA}$ & $5.9 \mathrm{aA}$ \\
\hline UnB1367 & $9.6 \mathrm{aA}$ & $17.6 \mathrm{bB}$ & $16.7 \mathrm{Bb}$ & $19.8 \mathrm{cB}$ & $7.0 \mathrm{aA}$ \\
\hline UnB1368 & $14.4 \mathrm{bA}$ & $12.2 \mathrm{bA}$ & $18.1 \mathrm{bA}$ & $21.3 \mathrm{cA}$ & $23.1 \mathrm{bA}$ \\
\hline UnB1369 & $14.6 \mathrm{bB}$ & $14.1 \mathrm{bB}$ & $12.0 \mathrm{Bb}$ & $0.0 \mathrm{aA}$ & $0.0 \mathrm{aA}$ \\
\hline UnB 1370 & $20.7 \mathrm{bB}$ & $5.5 \mathrm{aA}$ & $3.7 \mathrm{aA}$ & $13.1 \mathrm{bB}$ & $11.1 \mathrm{aB}$ \\
\hline UnB1371 & $0.0 \mathrm{aA}$ & $16.7 \mathrm{bB}$ & $0.0 \mathrm{aA}$ & $0.0 \mathrm{aA}$ & $0.0 \mathrm{aA}$ \\
\hline UnB1372 & $3.7 \mathrm{aA}$ & $0.0 \mathrm{aA}$ & $7.2 \mathrm{Aa}$ & $0.0 \mathrm{aA}$ & $3.7 \mathrm{aA}$ \\
\hline UnB1374 & $0.0 \mathrm{aA}$ & $2.8 \mathrm{aA}$ & $5.5 \mathrm{aA}$ & $9.3 \mathrm{bA}$ & $3.7 \mathrm{aA}$ \\
\hline UnB1375 & $30.9 \mathrm{cB}$ & $0.0 \mathrm{aA}$ & $37.0 \mathrm{cB}$ & $32.8 \mathrm{~dB}$ & $42.2 \mathrm{cB}$ \\
\hline
\end{tabular}

*Averages followed by the same lowercase letter in the column, and uppercase in the row, do not differ significantly by the Scott-Knott test $(\mathrm{P}<0.05)$

Médias seguidas pela mesma letra minúscula na coluna, e maiúscula na linha, não diferem significativamente pelo teste Scott-Knott $(\mathrm{P}<0,05)$.

\subsection{In vivo assays of Lasiodiplodia theobromae on teak cuttings}

In the greenhouse tests, all BCAs evaluated were able to control the canker, with significant differences among them and from the control treatment (Table 4). Trichoderma isolate CEN1153 presented 70.3\% control, differing from isolate CEN 162 , with $48.4 \%$. It was observed that the Bacillus sp. isolate had an intermediate control level compared to the Trichoderma isolates $(60.9 \%)$.

According to the interaction analyses, isolate CEN162 ( $T$. asperellum) completely controlled the canker in clone A when inoculated with the isolate of Lt CEN1226, differing statistically when inoculated with isolate Lt CEN1224, which exerted a 50\% control. When the same biocontrol fungus was inoculated into clone $\mathrm{B}$, the effect on the control was $50 \%$, with isolates CEN1224 and CEN1226 from the pathogen

Table 4 - Control levels of Lasiodiplodia theobromae with the application of three BCAs (Trichoderma sp. and Bacillus sp.) in two clones.

Tabela 4-Niveis de controle de Lasiodiplodia theobromae com a aplicação de três ACBs (Trichoderma sp. e Bacillus sp.) em dois clones.

\begin{tabular}{cccc}
\hline \multicolumn{4}{c}{ Antagonists } \\
\hline Control treatment & CEN162* & CEN1153 & UnB1366 \\
$0.0 \mathrm{~d}$ & $48.4 \mathrm{c}$ & $70.3 \mathrm{a}$ & $60.9 \mathrm{~b}$ \\
\hline
\end{tabular}

*Averages followed by the same letter do not differ statistically by the Scott-Knott test $(\mathrm{P}<0.05)$.
(Table 5); inoculation with isolate CEN 1153 (T. harzianum) resulted in control of approximately $50 \%$, when the Lt isolates CEN1224 and CEN1226 were applied to both clones (A and B), not statistically different from each other. Isolate UnB1366 (Bacillus sp.) also exerted control on isolate CEN1224 of $L$. theobromae $(50 \%)$, for both teak clones (A and B), differing statistically from each other. However, against isolate Lt CEN 1226 this bacterial isolate had no biocontrol effect.

Table 5 - Results of the significant interaction of the control level of two isolates on Lasiodiplodia theobromae, through the antagonistic effect of two isolates of Trichoderma and a strain of Bacillus.

Tabela 5 - Resultado da interação significativa do nível de controle de dois isolados Lasiodiplodia theobromae, através do efeito antagônico de dois isolados de Trichoderma e uma estirpe de Bacillus.

\begin{tabular}{lcc}
\hline & \multicolumn{2}{c}{ Lasiodiplodia isolates } \\
\hline $\begin{array}{l}\text { Antagonistic isolates } \\
\quad \text { x clones }\end{array}$ & CEN1224 & CEN1226 \\
CEN162 X Clone A & $50.0 \mathrm{bB} *$ & $100.0 \mathrm{aA}$ \\
CEN162 X Clone B & $50.0 \mathrm{bA}$ & $50.0 \mathrm{bA}$ \\
CEN1153 X Clone A & $43.7 \mathrm{bA}$ & $43.7 \mathrm{bA}$ \\
CEN1153 X Clone B & $50.0 \mathrm{bA}$ & $50.0 \mathrm{bA}$ \\
UnB1366 X Clone A & $50.0 \mathrm{bA}$ & $0.0 \mathrm{cB}$ \\
UnB1366 X Clone B & $100.0 \mathrm{aA}$ & $0.0 \mathrm{cB}$ \\
Control treatment & $0.00 \mathrm{cB}$ & $0.0 \mathrm{cB}$ \\
\hline
\end{tabular}

*Averages followed by the same lowercase letter in the column, and uppercase in the row, do not differ significantly by the Scott-Knott test $(\mathrm{P}<0.05)$.

Médias seguidas pela mesma letra minúscula na coluna, e maiúscula na linha, não diferem significativamente pelo teste Scott-Knott (P $<0,05)$.

Revista Árvore. 2018;42(3):e420304 


\section{DISCUSSION}

In the present study, it was observed that the BCAs CEN162 (T. asperellum) and CEN1153 (T. harzianum) exerted the greatest effect on the mycelial growth of Lasiodiplodia theobromae. Studies with isolates of Lt, obtained from banana fruits, done by Mortuza and Ilag (1999), showed that T. harzianum and T. viride were able to inhibit the pathogen growth in dual culture. Similarly, Adeniyi et al. (2013), evaluating the antagonistic effect of $T$. virens against Lt, from cashew tree inflorescence, showed total inhibition of mycelial growth of the pathogen. In view of the results obtained in this study, there is confirmation that the antagonistic action of Trichoderma isolates is intra- and interspecifically variable, corroborating the findings of Dennis and Webster (1971), Brodeur (2012) and Marques et al. (2018).

Bacillus sp. (UnB1366) exerted the greatest inhibition on mycelial growth of the pathogen. In studies conducted by Marques and Uesugi (2017), this same bacterial isolate was able to inhibit the in vitro growth of Ralstonia solanacearum Smith, Yabuuchi et al. (causal agent of eucalyptus wilt). In addition, the results corroborate those obtained by Kupper et al. (2004), who used four isolates of B. subtilis for the control of Guignardia citricarpa Kiely, confirming that they were able to inhibit fungal mycelial growth, and those of Maciel etal. (2017), who confirmed that Bacillus sp. moderately inhibited the mycelial growth of Lt obtained from pine (Pinus spp.).

In the in vivo tests, a positive correlation was observed with the in vitro tests, since the same antagonist isolates stood out. Isolates CEN162 and CEN1 153 (Trichoderma spp.) accounted for approximately 50\% disease control when Lt CEN1224 was inoculated into clones A and B. Similarly, Sultana and Ghaffar (2010) reported satisfactory levels of control of Lt in Lagenaria sp. However, when Lt isolate CEN1226 was inoculated into clone A, isolate CEN162 showed a control efficiency of $100 \%$. Contrary to what was expected, the isolate that stood out in the antagonistic clone and pathogen isolate interaction was CEN162, a T. asperellum isolate from soil cultivated with rice, compared to CEN1153, a T. harzianum isolate from soil cultivated with teak.

The isolate Lt CEN1224 was controlled by the bacterial isolate UnB1366 (Bacillus sp.) by 50 and 100\%, when inoculated on clones $\mathrm{A}$ and $\mathrm{B}$, respectively. This isolate, besides inhibiting the in vitro development of the bacterium causing eucalyptus wilt, also promoted the greatest phytomass increment and seed germination of this plant (Marques et al., 2014; Marques et al., 2013). In line with the results obtained in the present study, Maciel et al. (2017) reported that pine seeds inoculated with Lt and Bacillus sp. allowed a good biocontrol effect and final quality of cuttings.

\section{CONCLUSIONS}

Among the antagonistic microorganisms tested, CEN162 (T. asperellum), CEN1153 (T. harzianum) and UnB1366 (Bacillus sp.) are the BCAs that had the greatest effect against $L$. theobromae isolates in both experiments and, therefore, have potential to be used in disease management programs.

The results obtained corroborate previous ones, where a variation in the control levels of $L$. theobromae isolates was observed.

\section{ACKNOWLEDGMENTS}

The authors are grateful to CAPES (Coordination for the Improvement of Higher Education Personnel) for granting a master's degree scholarship to the first author and for the financial support provided by FAPDF (Federal District Research Support Foundation).

\section{REFERENCES}

Adeniyi DO, Adedeji AR, Oduwaye OF, Kolawole OO. Evaluation of biocontrol agents against Lasiodiplodia theobromae causing inflorescence blight of cashew in Nigeria. Journal of Agriculture and Veterinary Science. 2013;5(3):46-8.

Arguedas M. La roya de la teca Olivea tectonae (Rac.): consideraciones sobre su presencia en Panamá y Costa Rica Kurú. Revista Forestal. 2004;1:1-16.

Bautista-Baños S, Hernández-Lauzardo NA, Valle MGV, Hernández-Lopez M, Barka E, BosquezMolina E, et al. Chitosan as a potential natural compound to control pre and postharvest diseases of horticultural commodities. Crop Protection. 2006;25(2):108-18.

Bell DK, Wells HD, Markham CR. In vitro antagonism of Trichoderma species against six fungal plant pathogens. Phytopathology. 1982;72(4):379-82. 
Benato ARA. A indução de resistência no controle de doenças pós-colheita: frutas e hortaliças. Summa Phytopathologica. 2003;29:125-6.

Borges RCF, Santos MDM, Macedo MA, Martins I, Nascimento AG, Café-Filho AC et al. A trunk canker disease of Tectona grandis induced by Lasiodiplodia theobromae in Brazil. New Disease Reports. 2015;31.

Borges RCF. Etiologia do cancro da teca e caracterização patogênica e molecular de Lasiodiplodia theobromae [dissertação]. Brasília, DF: Universidade de Brasília; 2014.

Briceño A, Encinas O, Mohali S, Mora N, Molina Y. Biopreservantes contra el manchado azul de la madera de pino caribe. Revista Florestal Venezolana. 2008;52:143-8.

Brodeur J. Host specificity in biological control: insights from opportunistic pathogens. Evolutionary Applications. 2012;5(5):470-80.

Dennis C, Webster J. Antagonistic properties of species groups of Trichoderma III. Hyphal interactions. Transactions of the British Mycological Society. 1971;57(3):359-63.

Ferreira DF. SISVAR versão 5.0. Lavras: Universidade Federal de Lavras, Departamento de Ciências Exatas; 2007.

Firmino AC, Tozze HJ, Furtado EL. First report of Ceratocystis fimbriata causing wilt in Tectona grandis in Brazil. New Disease Reports. 2012;25:24.

Goh DKS, Galiana A. Vegetative propagation of teak. Jircas Working Report. 2000;16:35-43.

Kupper KC, Bettiol W, Correa EB, Moretto C. Potencialidade de Bacillus subtilis e Trichoderma spp. como agentes de biocontrole de Guinardia citricarpa. Fitopatologia Brasileira. 2004;29:129.

Maciel CG, Muniz MFB, Rolim JM, Michelon RMDN, Poletto T, Rabuske JE. Uso da microbiolização contra Lasiodiplodia theobromae em sementes de Pinus spp. Revista Árvore. 2017;41(3):e410301

Marques E, Aquiles KR, Blum LEB, Uesugi, CH. Bactérias extremófilas facultativas melhorando a

Revista Árvore. 2018;42(3):e420304 germinabilidade de sementes de Eucalyptus urophylla S.T. blake. Revista Árvore.

2014;38(3):489-94.

Marques E, Martins I, Mello SCM. Antifungal potential of crude extracts of Trichoderma spp. Biota Neotropica. 2018;18(1):e20170418.

Marques E, Uesugi CH. Avaliação de bactérias extremófilas facultativas na produção de fitomassa do híbrido "urograndis" de Eucalipto a partir de sementes. Revista Árvore. 2013;37(1):41-7.

Marques E, Uesugi CH. Bacteria from savanna-like Cerrado soils tolerant of $\mathrm{pH}$ and salinity and antagonistic to Ralstonia solanacearum. Indian Journal of Applied Research. 2017;7(10):610-3.

Menten JOM, Minussi CC, Castro C, Kimati H. Efeito de alguns fungicidas no crescimento micelial de Macrophomina phaseolina (Tass.) Goid. "in vitro". Fitopatologia Brasileira. 1976;1:57-66.

Mortuza MG, Ilag LL. Potential for biocontrol of Lasiodiplodia theobromae (Pat.) Griff. and Maubl. in banana fruits by Trichoderma species. Biological Control. 1999;15(3):235-40.

Papavizas GC. Survival of Trichoderma harzianum in soil and in pea bean rhizospheres. Phytopathology. 1982;72:121-2.

Pereira AL, Silva GS, Ribeiro VQ. Caracterização fisiológica, cultural e patogênica de diferentes isolados de Lasiodiplodia theobromae. Fitopatologia Brasileira. 2006;31:572-8.

Pereira AVS, Martins RB, Michereff SJ, Silva MB, Câmara MPS. Sensitivity of Lasiodiplodia theobromae from Brazilian papaya orchards to MBC and DMI fungicides. European Journal of Plant Pathology. 2012;32:489-98.

Punithalingam E. Plant diseases attributed to Botryodiplodia theobromae. Vaduz: Pat. J. Cramer; 1980. 121p.

Sales Júnior R, Nunes GHS, Lima LL, Guimarães IM, Morais PLD. Controle químico da podridão peduncular causada por Lasiodiplodia theobromae em mangas. Revista Brasileira de Fruticultura. 2009;31:907-10. 
Silva ACF. Uso de radiação gama para obtenção de mutantes de Trichoderma harzianum Rifai e $T$. viride Pers. com capacidade melhorada no controle de Sclerotinia sclerotiorum (Lib.) de Bary [tese]. São Paulo: Universidade de São Paulo; 1997.
Sultana N, Ghaffar A. Effect of fungicides and microbial antagonists in the control of Lasiodiplodia theobromae, the cause of seed rot, seedling and root infection of bottle gourd. Journal of Agricultural Research. 2010;23(1):1-2. 